Jurnal Dinamika Sosial Ekonomi Vol.21 No.1, Juni 2020 : 79-91

ISSN 1411-593X (print); ISSN 2721-3137 (online)

\title{
ANALISIS POTENSI SEKTOR PERTANIAN, KEHUTANAN, DAN PERIKANAN SEBAGAI DASAR PERENCANAAN PEMBANGUNAN EKONOMI KABUPATEN PACITAN
}

\section{The Analysis Potential of Agriculture, Forestry, and Fishery Sectors as a Basic For Economic Development Plan in Pacitan Regency}

\author{
Intan Aisyah*, Juarini, Dwi Aulia Puspitaningrum \\ Program Studi Agribisnis Jurusan Agribisnis Fakultas Pertanian \\ Universitas Pembangunan Nasional "Veteran" Yogyakarta \\ Jl. SWK 104 (Lingkar Utara) Condongcatur Yogyakarta Indonesia 55283 \\ *Email korespondensi: intanaisyah17@gmail.com
}

Diterima tanggal : 16 Juni 2020 ; Disetujui tanggal 29 Juni 2020

\begin{abstract}
The purposes of the research were to 1. analyze the basic sub-sectors of the agriculture, forestry, and fishery sectors in Pacitan Regency. 2. Changes in the economic structure of the agriculture, forestry, and fisheries sub-sectors of Pacitan Regency compared to Jawa Timur Province. 3. Make a map of the agriculture, forestry, and fisheries sectors in Pacitan Regency based on Geographic Information System. The methodology of this research was quantitative descriptive with the case study. The method of retrieval data used quantitative data from PDRB, subcategories, production and price from secondary data sourced using documentation and recording. Data analysis technique is a contribution, location quotient (LQ), shift share, multiplier effect, ArcGIS. The results of these research are the contribution of agriculture, forestry, and fishery is potential for the economy in Pacitan Regency. 2. The basic subsectors are the corps and the fishery sub-sector. 3. The changes in the economic structure show that the corps, plantation, agriculture service and hunting subsector happen changes in economic stucture. 4. Multiplier Effect the food corps sub-sector is 2,81 and the fishery sub-sector is 3,43. 5. Based on ArcGIS 10.2, the map show the corps sub-sector is located in Donorojo Sub-District, fishery subsector in Pacitan Sub-District and livestock in Tulakan Sub-District.
\end{abstract}

Keywords: basic sub-sectors, economic development, economic structure, spatial GIS., Pacitan. 


\begin{abstract}
ABSTRAK
Penelitian ini bertujuan menganalisis 1. sub sektor basis dari sektor pertanian, kehutanan, dan perikanan2.transformasi struktur ekonomi sub sektor pertanian, kehutanan, dan perikanan dibandingkan dengan Provinsi Jawa Timur 3. sektor pertanian, kehutanan, dan perikanan di Kabupaten Pacitan dengan pendekatan spasial berbasis GIS (Geographic Information System).Metode penelitian yang digunakan deskriptif kuantitatif. Metode pelaksanaannya adalah studi kasus. Metode pengambilan data menggunakan macam data sekunder dengan sumber data dari BPS dan Bappeda, cara pengambilan data menggunakan teknik dokumentasi dan pencatatan. Teknik analisis data berupa Location Quotient, Shift Share dan ArcGIS 10.2. Hasil penelitian ialah 1. Sub sektor basis ialah sub sektor tanaman pangan dan sub sektor perikanan 2. Sub sektor pertaninan, kehutanan, dan perikanan tidak mengalami transformasi struktur ekonomi. 3. Potensi Kabupaten Pacitan menggunakan ArcGIS 10.2 berupa peta spasial menunjukkan bahwa potensi sub sektor tanaman pangan berada di Kecamatan Donorojo sub sektor perikanan di Kecamatan Pacitan dan sub sektor peternakan di Kecamatan Tulakan.
\end{abstract}

Kata Kunci: Pacitan, pembangunan ekonomi, subsektor basis, struktur ekonomi, spasial GIS.

\title{
PENDAHULUAN
}

Pembangunan pada suatu daerah harus dilakukan dengan memanfaatkan sumberdaya-sumberdaya yang ada.Pembangunan dengan menggunakan potensi yang dimiliki daerah dapat meningkatkan pendapatan masyarakat. Dalam melakukan pembangunan wilayah perlu adanya perencanaan. Distribusi Persentase PDRB Menurut Kabupaten/Kota di Provinsi Jawa Timur Pada Tahun 2015-2019 (Persen) terlihat bahwa selama lima tahun berturut-turut distribusi PDRB Kabupaten Pacitan terhadap Provinsi Jawa Timur terkecil keenam, dan di luar kota di Provinsi Jawa Timur Kabupaten Pacitan menjadi kabupaten dengan distribusi PDRB terendah.

Berdasarkan PDRB Menurut Lapangan Usaha Atas Dasar Harga Konstan 2010 Kabupaten Pacitan (Persen) diketahui bahwa dari tahun 2011-2018 sektor pertanian, kehutanan, dan perikanan menjadi penyumbang PDRB tertinggi akan tetapi dilihat dari laju pertumbuhan PDRB sektor pertanian, kehutanan, dan perikanan selama delapan tahun berturut-turut mengalami naik turun. Letak geografis Kabupaten Pacitan yang sebagian besar dari wilayahnya berupa bukit dan gunung, jurang terjal serta termasuk deretan pegunungan seribu dengan 
Aisyah et.al., Analisis Potensi Sektor Pertanian, Kehutanan, dan Perikanan..

tanahnya berupa kapur yang kurang cocok untuk pertanian. Selain letak geografisnya Kabupaten Pacitan terkenal akan kabupaten yang sering mengalami kekeringan. Perlu adanya menggali sub sektor yang menjadi potensi yang dapat dikembangkan di Kabupaten Pacitan berdasarkan kondisi alam, kondisi sosial maupun ekonomi dan sumberdaya alam dari daratan maupun perairan yang dimiliki Kabupaten Pacitan.

Berdasarkan teori basis, kegiatan ekonomi dalam pembangunan ekonomi dibedakan menjadi dua yaitu kegiatan basis dan kegiatan non basis. Kegiatan basis ini akan menunjang dalam pembangunan ekonomi karena kegiatan basis ini dapat menyediakan barang maupun jasa yang dibutuhkan oleh daerah lainnya, sehingga basis juga dikatakan ekspor. Kegiatan ekonomi yang melayani pasar di daerah tersebut, dinamakan kegiatan ekonomi non basis (Arsyad, 1999). Menurut Hayami dan Ruttan (1971) dalam Vaulina dan Septina (2014), perubahan struktur sektor pertanian yaitu adanya perubahan pola komposisi produksi, urutan produksi dan perubahan sumberdaya yang digunakan. Pemetaan sub sektor potensi menggunakan Sistem Informasi Geografis (SIG) diperlukan untuk mempermudah pembaca dalam mengetahui potensi dari sub sektor pertanian, kehutanan, dan perikanan di Kabupaten Pacitan.

Berdasarkan latar belakang tersebut, penelitian ini bertujuan 1 . menganalisis sub sektor basis dari sektor pertanian, kehutanan, dan perikanan 2 . menganalisis transformasi struktur ekonomi sub sektor pertanian, kehutanan, dan perikanan dibandingkan dengan Provinsi Jawa Timur 3. membuat gambar peta dari sektor pertanian, kehutanan, dan perikanan di Kabupaten Pacitan dengan pendekatan spasial berbasis GIS (Geographic Information System)..

\section{METODE PENELITIAN}

Penelitian ini dilakukan dengan pendekatan deskriptif kuantitatif yang menggunakan data runtun waktu (time series) mulai tahun 2010-2018. Metode pelaksanaan penelitian menggunakan studi kasus. Dalam penelitian ini yang menjadi kasus adalah Kabupaten Pacitan mempunyai kondisi alam yang berupa bukit dan gunung, jurang terjal serta termasuk deretan pegunungan seribu dengan 
jenis tanahnya berupa kapur sehingga kurang cocok untuk pertanian serta sering mengalami kekeringan namun sektor pertanian, kehutanan, dan perikanan menjadi penyumbang PDRB di Kabupaten Pacitan tertinggi. Metode pengambilan data menggunakan data sekunder yang bersumber dari BPS dan Bappeda Kabupaten Pacitan dengan cara dokumentasi dan pencatatan. Data yang diperoleh dianalisis menggunakan, location quotient, shift share, dan ArcGIS.

Menganalisis Sub Sektor Basis Dari Sektor Pertanian, Kehutanan, Dan Perikanan Di Kabupaten Pacitan

Metode Location Quotient (LQ) digunakan untuk mengkaji kondisi perekonomian, mengarah pada identifikasi spesialisasi atau basis kegiatan perekonomian (Sapriadi dan Hasbiullah, 2015). Analisis ini merupakan usaha untuk mengukur kosentrasi dari satu kegiatan ekonomi dalam satu daerah dengan cara membandingkan perannya dalam perekonomian daerah itu dengan peranan kegiatan ekonomi sejenis dalam perekonomian regional atau nasional (Arifin, 2014 dalam Saputri dan Arfida, 2018).Rumusnya sebagai berikut (Tarigan, 2007).

$\mathrm{LQ}=\frac{x i / P D R B}{X i / P N B}$

Keterangan:

$\mathrm{xi}=$ PDRB sub sektor pertanian, kehutanan, dan perikanan Kabupaten Pacitan

PDRB = PDRB sektor pertanian, kehutanan, dan perikanan Kabupaten Pacitan

$\mathrm{Xi} \quad=$ PDRB sub sektor pertanian, kehutanan, dan perikanan Provinsi Jawa Timur

PNB = PDRB sektor pertanian, kehutanan, dan perikanan Provinsi Jawa Timur

Keterangan hasil analisis Location Quotient (LQ) oleh Tirani, Pranoto dan Moelyo (2018) adalah sebagai berikut:

$\begin{array}{lll}\text { LQ>1 } & : & \begin{array}{l}\text { Sub sektor tersebut merupakan sub sektor } \\ \text { unggulan (basis) }\end{array} \\ \text { LQ<1 } & : \quad \begin{array}{l}\text { Sub sektor tersebut bukan sub sektor unggulan } \\ \text { (non basis) }\end{array}\end{array}$


Aisyah et.al., Analisis Potensi Sektor Pertanian, Kehutanan, dan Perikanan..

$\mathrm{LQ}=1 \quad$ : $\quad$ Produksi sub sektor yang bersangkutan hanya cukup untuk kebutuhan setempat

Menganalisis Transformasi Struktur EkonomiSub Sektor Pertanian, Kehutanan Dan Perikanan Kabupaten Pacitan Dibandingkan Dengan Provinsi Jawa Timur

Transformasi struktural didefinisikan sebagai perubahan struktur ekonomi dari sektor tradisonal yang memiliki produktivitas rendah menuju sektor ekonomi dengan produktivitas tinggi (Szirmai et al., 2012 dalam Romli, Hutagaol dan Priyarsono, 2016).Untuk menganalisis transformasi struktur ekonomi menggunakan analisis Shift Share yang terdiri dari national share, proportional shift dan differential shift digunakan untuk melihat transformasi struktur ekonomi. Menurut Tarigan (2007) bentuk persamaan dari analisis shift share adalah:

$$
\begin{aligned}
& \Delta \mathrm{Er}=\mathrm{Ns}+\mathrm{Pr}+\mathrm{Dr} \\
& \text { Dimana } \\
& \mathrm{NS}_{\mathrm{i}, \mathrm{r}, \mathrm{t}}=\sum_{t=1}^{n}\left\{E_{\mathrm{r}, \mathrm{i}, \mathrm{t}-\mathrm{n}}\left(\mathrm{E}_{\mathrm{N}, \mathrm{t}} / \mathrm{E}_{\mathrm{N}, \mathrm{t}-\mathrm{n}}\right)-\mathrm{E}_{\mathrm{r}, \mathrm{i}, \mathrm{t}-\mathrm{n}}\right\} \\
& \mathrm{P}_{\mathrm{i}, \mathrm{r}, \mathrm{t}}=\sum_{t=1}^{n}\left[\left\{\left(E_{\mathrm{N}, \mathrm{i}, \mathrm{t}} / \mathrm{E}_{\mathrm{N}, \mathrm{i}, \mathrm{t}}-\mathrm{n}\right)-\left(\mathrm{E}_{\mathrm{N}, \mathrm{t}} / \mathrm{E}_{\mathrm{N}, \mathrm{t}-\mathrm{n}}\right)\right\} \times \mathrm{E}_{\mathrm{r}, \mathrm{i}, \mathrm{t}-\mathrm{n}}\right] \\
& \mathrm{D}_{\mathrm{i}, \mathrm{r}, \mathrm{t}}=\sum_{t=1}^{n}\left\{E_{\mathrm{r}, \mathrm{i}, \mathrm{t}^{-}}\left(\mathrm{E}_{\mathrm{N}, \mathrm{i}, \mathrm{t}} / \mathrm{E}_{\mathrm{N}, \mathrm{i}, \mathrm{t}-\mathrm{n}}\right) \times \mathrm{E}_{\mathrm{r}, \mathrm{i}, \mathrm{t}-\mathrm{n}}\right\}
\end{aligned}
$$

Keterangan:

$$
\begin{aligned}
\Delta & =\begin{array}{l}
\text { Pertumbuhan, angka akhir (tahun } \mathrm{t} \text { ) dikurangi dengan angka awal } \\
\mathrm{N}
\end{array} \\
\mathrm{r} & =\text { Wilayah Provinsi Jawa Timur } \\
\mathrm{E} & =\text { Nilayah daerah Kabupaten Pacitan } \\
\mathrm{i} & =\text { Sektor yang akan diteliti } \\
\mathrm{t} & =\text { Tahun pada saat ini } \\
\mathrm{t}-\mathrm{n} & =\text { Tahun sebelumnya } \\
\mathrm{NS} & =\text { National Share } \\
\mathrm{Pr} & =\text { Proportional Shift }
\end{aligned}
$$


Jurnal Dinamika Sosial Ekonomi, 21 (1) : 79-91

Dr $=$ Differential Shift

Membuat Peta Gambar Dari Sektor Pertanian, Kehutanan, Dan Perikanan Di Kabupaten Pacitan Dengan Pendekatan Spasial Berbasis Geographic Information System

Analisis Sistem Informasi Geografis (SIG) menggunakan aplikasi ArcGIS 10.2 dengan peta dasar Kabupaten Pacitan kemudian dianaliss dijadikan peta yang menggambarkan kecamatan-kecamatan di Kabupaten Pacitan yang mempunyai potensi untuk dikembangkan dari sub sektor pertanian, kehutanan dan perikanan.Data dalam SIG dikelompokkan dalam dua bagian, yaitu data spasial dan data non spasial. Data spasial merupakan data yang memuat tentang lokasi suatu objek dalam peta berdasarkan posisi geografi objek tersebut di dalam bumi dengan menggunakan sistem koordinat (Ahaliki, 2016).

\section{HASIL DAN PEMBAHASAN}

Sub Sektor BasisDari Sektor Pertanian, Kehutanan, Dan Perikanan Di Kabupaten Pacitan

Kegiatanekonomi dalam pembangunan ekonomi dibedakan menjadi dua yaitu kegiatan basis dan kegiatan non basis. Sub sektor basis ini akan menunjang dalam pembangunan ekonomi. Dalam menggolong sub sektor pertanian, kehutanan, dan perikanan termasuk kedalam kegiatan ekonomi basis atau non basis, maka menggunakan analisis Location Quotient (LQ) pada tahun 2010-2018, dimulai pada tahun 2010 karena berdasarkan PDRB harga konstan digunakan tahun dasar 2010 dan berakhir pada tahun 2018 karena berlangsungnya penelitian ketersediaan data terakhir pada tahun 2018. Hasil dari analisis Location Quotient (LQ) yang menunjukkan sub sektor basis dapat dilihat pada Tabel 2. 
Aisyah et.al., Analisis Potensi Sektor Pertanian, Kehutanan, dan Perikanan..

Tabel 2 HasilLocation Quotient (LQ) Sub Sektor Pertanian, Kehutanan, dan Perikanan Kabupaten Pacitan Tahun 2010-2018.

\begin{tabular}{|c|c|c|c|c|c|c|c|c|c|c|}
\hline \multirow{2}{*}{ Sub Sektor } & \multicolumn{9}{|c|}{ Tahun } & \multirow{2}{*}{$\begin{array}{l}\text { Rata } \\
\text {-rata }\end{array}$} \\
\hline & 2010 & 2011 & 2012 & 2013 & 2014 & 2015 & 2016 & 2017 & 2018 & \\
\hline Tanaman & 1,16 & 1,17 & 1,14 & 1,11 & 1,11 & 1,09 & 1,07 & 1,05 & 1,02 & 1,10 \\
\hline $\begin{array}{l}\text { Pangan } \\
\text { Tanaman } \\
\text { Hortikultura }\end{array}$ & 0,57 & 0,56 & 0,56 & 0,56 & 0,55 & 0,54 & 0,51 & 0,52 & 0,50 & 0,54 \\
\hline Perkebunan & 0,73 & 0,70 & 0,68 & 0,67 & 0,66 & 0,66 & 0,68 & 0,69 & 0,67 & 0,68 \\
\hline Peternakan & 0,77 & 0,77 & 0,80 & 0,80 & 0,81 & 0,82 & 0,81 & 0,81 & 0,79 & 0,80 \\
\hline $\begin{array}{l}\text { Jasa } \\
\text { Pertanian } \\
\text { dan } \\
\text { Perkebunan }\end{array}$ & 0,57 & 0,57 & 0,55 & 0,56 & 0,55 & 0,61 & 0,60 & 0,60 & 0,57 & 0,58 \\
\hline $\begin{array}{l}\text { Kehutanan } \\
\text { dan } \\
\text { Penebangan } \\
\text { Kayu }\end{array}$ & 0,52 & 0,52 & 0,56 & 0,60 & 0,63 & 0,64 & 0,69 & 0,67 & 0,67 & 0,61 \\
\hline Perikanan & 1,63 & 1,68 & 1,66 & 1,66 & 1,65 & 1,66 & 1,68 & 1,67 & 1,72 & 1,67 \\
\hline
\end{tabular}

Sumber: Badan Pusat Statistika Kabupaten Pacitan, 2019 (data diolah).

Dari analisis Location Quotient (LQ) diketahui bahwa yang menjadi sub sektor basis ialah sub sektor tanaman pangan dengan rata-rata LQ sebesar 1,10 dan sub sektor perikanan dengan rata-rata LQ sebesar 1,67. Sub sektor tanaman pangan dan perikanan masuk kedalam sub sektor basis dikarenakan hasil rata-rata LQ lebih dari 1. Hal ini menunjukkan bahwa sub sektor tanaman pangan dan perikanan mampu memenuhi kebutuhan pasar domestik maupun luar. Sub sektor lainnya tidak masuk ke dalam sub sektor basis karena hasil rata-rata LQ kurang dari 1 yang berarti bahwa sub sektor ini hanya mampu memenuhi kebutuhan pasar domestik. Lebih memprioritaskan sub sektor tanaman pangan dan perikanan karena dapat digunakan untuk memenuhi kebutuhan di Kabupaten Pacitan maupun dapat di ekspor.Penelitian ini sesuai dengan penelitian (Sari dan Bangun, 2019) mengenai Analisis Peranan Sektor Pertanian, Kehutanan, dan Perikanan Pada Perekonomian Kabupaten Deli Serdang yang menunjukkan bahwa sub sektor tanaman pangan. perkebunan semusim, tanaman hortikultura tahunan, peternakan, jasa pertanian dan perburuan, serta perikanan merupakan sub sektor unggulan berdasarkan analisis Location Quotient (LQ). 
Jurnal Dinamika Sosial Ekonomi, 21 (1) : 79-91

\section{Analisis Transformasi Struktur Ekonomi Sub SektorPertanian, Kehutanan Dan Perikanan Kabupaten Pacitan Dibandingkan Dengan Provinsi Jawa Timur}

Pertumbuhan ekonomi yang berlangsung secara berkesinambungan dalam suatu kurun waktu tertentu dapat mengubah struktur ekonomi. Perubahan struktur ekonomi ini dilihat menggunakan shift share. Proses transformasi struktural ditandai oleh perubahan struktur ekonomi yang dicerminkan oleh perubahan kontribusi sektoral (shift share) di dalam pendapatan nasional (Arsyad, 2016). Berikut ini adalah hasil shift share sub sektor pertanian, kehutanan, dan perikanan.

Tabel 3. Hasil Analisis Shift ShareSub Sektor Pertanian, Kehutanan, dan Perikanan di Kabupaten Pacitan Pada Tahun 2010-2018

\begin{tabular}{lrrrrrrrrr}
\hline Sub Sektor & $\begin{array}{r}2010- \\
2011\end{array}$ & $\begin{array}{r}2011- \\
2012\end{array}$ & $\begin{array}{r}2012- \\
2013\end{array}$ & $\begin{array}{r}2013- \\
2014\end{array}$ & $\begin{array}{r}2014 \\
2015\end{array}$ & $\begin{array}{r}2015- \\
2016\end{array}$ & $\begin{array}{r}2016- \\
2017\end{array}$ & $\begin{array}{r}2017- \\
2018\end{array}$ & $\begin{array}{r}\text { Rata- } \\
\text { Rata }\end{array}$ \\
\hline $\begin{array}{l}\text { Tanaman } \\
\text { Pangan }\end{array}$ & 78,27 & 87,38 & 72,10 & 91,85 & 98,95 & 84,55 & $-55,35$ & 16,61 & 59,29 \\
$\begin{array}{l}\text { Tanaman } \\
\text { Hortikultura }\end{array}$ & 6,34 & 8,32 & 7,89 & 12,63 & 13,43 & 11,21 & 11,56 & 3,44 & 9,35 \\
$\begin{array}{l}\text { Perkebunan } \\
\text { Peternakan }\end{array}$ & 4,56 & 44,29 & 18,78 & 35,91 & 30,40 & 24,58 & 19,48 & $-14,99$ & 20,38 \\
Jasa & 4,10 & 51,72 & 55,60 & 60,35 & 51,36 & 38,68 & 63,65 & 40,31 & 50,60 \\
$\begin{array}{l}\text { Pertanian } \\
\text { dan }\end{array}$ & & & & & & & & & \\
$\begin{array}{l}\text { Perburuan } \\
\text { Kehutanan }\end{array}$ & 1,00 & 1,38 & 1,87 & 2,17 & 3,52 & 1,91 & 1,72 & $-1,22$ & 1,54 \\
dan & & & & & & & & & \\
$\begin{array}{l}\text { Penebangan } \\
\text { Kayu }\end{array}$ & 5,08 & 17,02 & 11,38 & 12,82 & 10,44 & 4,57 & 8,58 & 4,34 & 9,28 \\
Perikanan & 60,57 & 126,08 & 117,11 & 134,04 & 117,20 & 105,94 & 141,78 & 178,64 & 122,67 \\
\hline Jumlah & 198,93 & 336,19 & 284,73 & 349,77 & 325,30 & 271,44 & 191,42 & 227,13 & 273,11 \\
\hline Sumber: BPS Ka & & & & & & & & \\
\end{tabular}

Sumber: BPS Kabupaten Pacitan, 2019 (data diolah).

Dari hasil analisis shift share terlihat bahwa sub sektor pertanian, kehutanan, dan perikanan tidak mengalami transformasi struktur ekonomi. Hal ini ditunjukkan dari hasil rata-rata shift share per sub sektor. Hasil analisis shift share ini menunjukkan bahwa sub sektor pertanian, kehutanan, dan perikanna tetap menjadi sub sektor primer yang berarti tidak adanya transformasi dilihat dari 
Aisyah et.al., Analisis Potensi Sektor Pertanian, Kehutanan, dan Perikanan..

struktur ekonomi pada sub sektor pertanian, kehutanan, dan perikanan. Berdasarkan rata-rata dari analisis shift share tiga sub sektor tertinggi ialah sub sektor tanaman pangan, perikanan, dan peternakan, sehingga pemerintah Kabupaten Pacitan perlu mempertahankan ketiga sub sektor ini untuk dasar perencanaan pembangunan ekonomi. Dari hasil perhitungan analisis shift share pada penelitian ini sesuai dengan penelitian dari Ridlo dan Susilowati (2018) yang berjudul Analisis Sektor Pertanian, Kehutanan, Perikanan Terhadao PDRB di Kabupaten Lamongan yang menunjukkan hasil shift share berindikasi bahwa pertumbuhan sektor pertanian di Provinsi Jawa Timur berpengaruh positif terhadap pertumbuhan sektor pertanian di Kabupaten Lamongan.

\section{Peta Gambar Dari Sektor Pertanian, Kehutanan, Dan Perikanan Di Kabupaten Pacitan Dengan Pendekatan Spasial Berbasis Geographic Information System}

Dalam melakukan perencanaan pembangunan ekonomi perlu melakukan pemetaan terhadap sub sektor potensi yang nantinya dapat dikembangkan di daerah tersebut. Pemetaan ini dilakukan dengan aplikasi ArcGIS 10.2. ArcGIS desktop merupakan sebuah solusi sofware aplikasi sistem informasi geografis yang integral. ArcGIS dikembangkan oleh ESRI (Enviromental System Research institute). ArcGIS dekstop merupakan salah satu dari sekian banyak produk yang saling terkait dibidang pemetaan digital yang dikembangkan oleh ESRI (Awaludin, 2017 dalam Nurdiawan dan Harumi, 2018).Adanya pemetaan untuk mempermudah pembaca dalam mengetahui potensi sub sektor pertanian, kehutanan, dan perikanan yang ada di Kabupaten Pacitan melalui gambar. Peneliti membuat tiga peta berdasarkan hasil dari analisis Location Quotient (LQ) dan dari perhitungan Shift Share yang menunjukkan sub sektor potensi yaitu sub sektor tanaman pangan, perikanan dan sub sektor peternakan. Dibawah ini adalah peta mengenai persebaran nilai produksi tanaman pangan. 


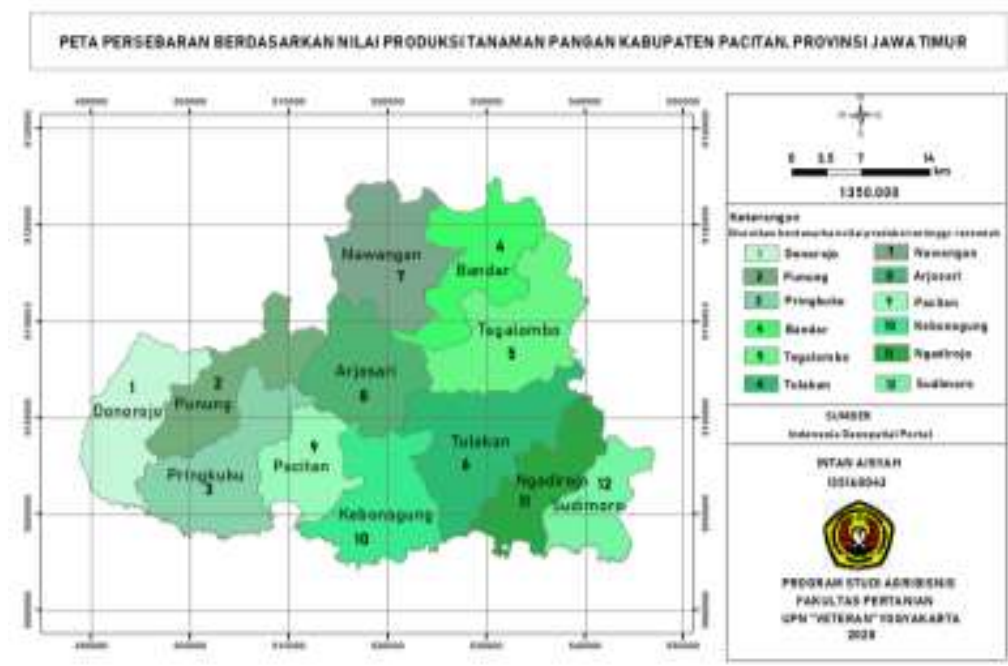

Gambar 1. Peta Persebaran Nilai Produksi Tanaman Pangan Sumber: Badan Pusat Statistika Kabupaten Pacitan, 2019

Berdasarkan Gambar 1. Peta Persebaran Nilai Produksi Tanaman Pangan terlihat bahwa Kecamatan Donorojo dengan nilai produksi tanaman pangan tertinggi. Dari hasil produksi dan harga tanaman pangan tertinggi di Kecamatan Donorojo sehingga potensi dalam sub sektor tanaman pangan.Oleh karena itu pemerintah Kabupaten Pacitan dapat mengembangkan sub sektor tanaman pangan dari Kecamatan Donorojo. Komoditas pada sub sektor tanaman pangan di Kecamatan Donorojo ini terdiri dari komoditas padi, kedelai, jagung, ubi kayu, ubi jalar, kacang tanah dan kacang hijau.

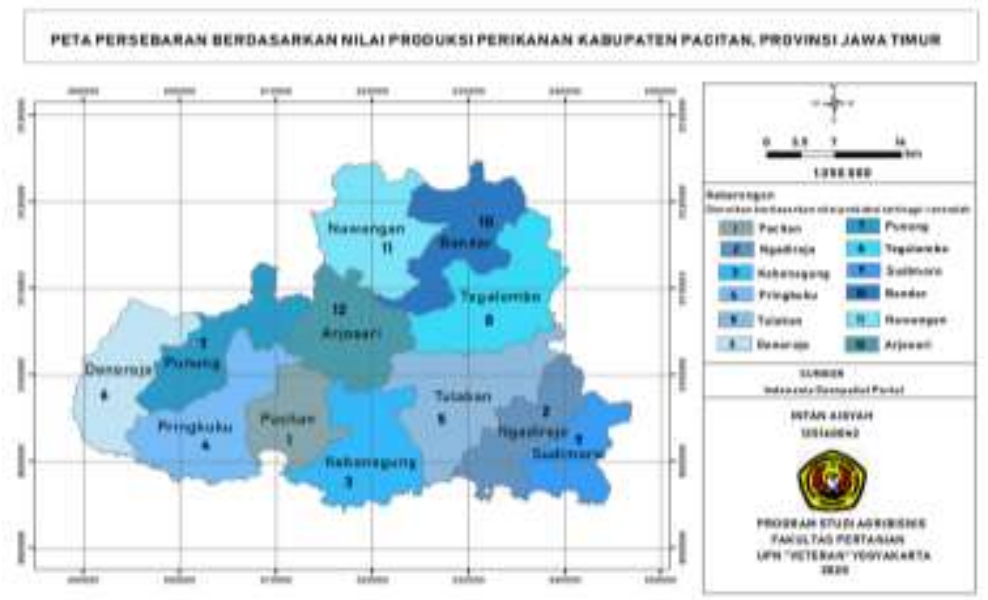

Gambar 2. Peta Persebaran Berdasarlam Nilai Produksi Perikanan

Sumber: Badan Pusat Statistika Kabupaten Pacitan, 2019 
Aisyah et.al., Analisis Potensi Sektor Pertanian, Kehutanan, dan Perikanan..

Dari Gambar 2. Peta Persebaran Berdasarkan Nilai Produksi Perikanan terlihat produksi dari sub sektor perikanan paling tinggi berada di Kecamatan Pacitan. Nilai produksi sub sektor perikanan tertinggi ini menjadikan Kecamatan Pacitan potensi di perikanan. Lebih baik mengembangkan sub sektor perikanan di Kecamatan Pacitan karena sebagai kecamatan yang berpotensi di sub sektor perikanan. Sub sektor perikanan ini terdiri dari perikanan laut dan perikanan umum. Kecamatan Pacitan memegang peranan penting di sub sektor perikanan karena dilihat dari perikanan laut maupun umum, Kecamatan Pacitan lebih unggul dibandingkan dengan kecamatan lainnya yang berada di Kabupaten Pacitan.

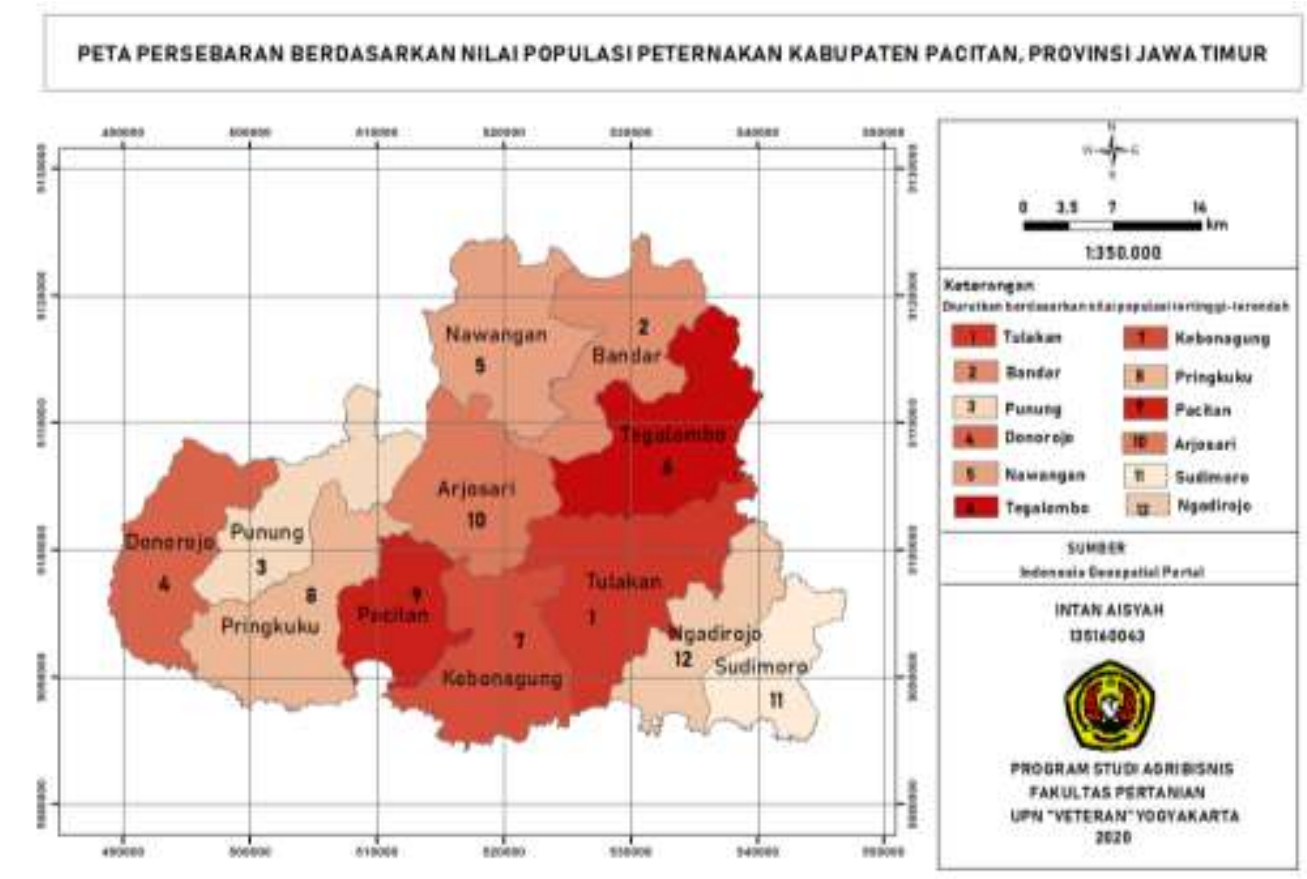

Gambar 3. Peta Persebaran Berdasarkan Nilai Populasi Peternakan Sumber: Badan Pusat Statistika Kabupaten Pacitan, 2019

Dari Gambar 3. Peta Persebaran Berdasarkam Nilai Populasi Peternakan terlihat bahwa Kecamatan Tulakan merupakan kecamatan dengan nilai populasi peternakan paling tinggi. Adanya nilai populasi paling tinggi ini menyebabkan Kecamatan Tulakan berpotensi di sub sektor peternakan. Dari peta ini mempermudahkan dalam pengembangan pada sub sektor peternakan dengan melihat kecamatan dari nilai populasi tertinggi hinga terendah. Pemerintah 
Kabupaten Pacitan juga dapat melihat bahwa Kecamatan Tulakan berpotensi pada sub sektor peternakan.Berdasarkan peta gambar yang telah disajikan oleh peneliti maka dapat dilakukan dasar perencanaan pembangunan ekonomi dari sektor pertanian, kehutanan, dan perikanan lebih baik mengembangkan sub sektor tanaman pangan di Kecamatan Donorojo, sub sektor perikanan di Kecamatan Pacitan dan sub sektor peternakan di Kecamatan Tulakan. Hal ini dikarenakan nilai produksi dan populasi tertinggi di pada kecamatan tersebut.

\section{KESIMPULAN DAN SARAN}

\section{Kesimpulan}

Analisis yang telah dilakukan dapat disimpulkan bahwa sub sektor basis dari sektor pertanian, kehutanan, dan perikanan ialah sub sektor tanaman pangan dan perikanan. Sub sektor pertanian, kehutanan, dan perikanan tidak mengalami transformasi struktur ekonomi. Potensi Kabupaten Pacitan menggunakan ArcGIS 10.2 berupa peta spasial menunjukkan bahwa berdasarkan nilai produksi potensi sub sektor tanaman pangan di Kecamatan Donorojo, potensi sub sektor perikanan di Kecamatan Pacitan, sedangkan berdasarkan nilai populasi potensi sub sektor peternakan di Kecamatan Tulakan

\section{Saran}

Sub sektor tanaman pangan dan perikanan lebih diprioritaskan karena dapat digunakan untuk memenuhi kebutuhan di Kabupaten Pacitan maupun dapat di ekspor. Sub sektor tanaman pangan, perikanan dan peternakan tertinggi berdasarkan analisis shift share sehingga mempertahankan ketiga sub sektor ini untuk dasar perencanaan pembanguna ekonomi. Perencanaan pembangunan ekonomi dari sektor pertanian, kehutanan, dan perikanan lebih baik mengembangkan sub sektor tanaman pangan di Kecamatan Donorojo, sub sektor perikanan di Kecamatan Pacitan dan sub sektor peternakan di Kecamatan Tulakan. Hal ini dikarenakan nilai produksi dan populasi tertinggi di pada kecamatan tersebut. 
Aisyah et.al., Analisis Potensi Sektor Pertanian, Kehutanan, dan Perikanan..

\section{DAFTAR PUSTAKA}

Ahaliki, Budiyanto. (2016). Sistem Indormasi Geografis (SIG) Pemetaan dan Analisis Daerah Pertanian di Kabupaten Gorontalo. Jtech, 4, 2: 116122.

Arsyad, Lincolin. (1999). Pengantar Perencanaan Pembangunan Ekonomi Daerah Edisi 1. Yogyakarta: BDFE-Yogyakarta.

Saputri, Intan dan Arfida Boedi. 2018. Analisis Sektor Ekonomi Unggulan Pada Kabupaten/Kota Di Provinsi Sumatera Selatan. Jurnal Ilmu Ekonomi, 2, 2: $217-229$.

Lubis, Malik A. Aziz. (2018). Mengenal GIS. <labgis.si.fti.unand.ac.id>. Diakses pada 20 September 2019. Pukul 06.00 WIB.

Nurdiawan, Odi dan Harumi Putri. (2018). Pemetaan Daerah Rawan Banjir Berbasis Sistem Informasi Geografis Dalam Upaya Mengoptimalkan Langkah Antisipasi Bencana. Infotech Journal, 4, 2: 2460-1861.

Ridlo, A R dan Susilowati, D. (2018). Analisis Sektor Pertanian, Kehutanan, Perikanan Terhadap PDRB di Kabupaten Lamongan. Jurnal Ilmu Ekonomi, 2, 1: 14-25.

Romli, M S. Hutagaol, M P, Proyarsono, D S. (2016). Transformasi Struktural: Faktor-Faktor dan Pengaruhnya Terhadap Disparitas Pendapatan Madura. Jurnal Ekonomi dan Kebijakan Pembangunan, 5, 1: 25-44.

Sapriadi dan Hasbiullah. (2015). Analisis Penentuan Sektor Unggulan Perekonomian Kabupaten Bulukumba. Iqtisaduna, 1,1: 71-86.

Sari, F W A W dan Bangun, R H B. (2019). Analisis Peranan Sektor Pertanian, Kehutanan, dan Perikanan Pada Perekonomian Kabupaten Deli Serdang. J. Agroland, 26, 3: 198-211.

Tarigan, Robinson. (2007). Ekonomi Regional, Teori dan Aplikasi. Jakarta: PT. Bumi Aksara.

Tirani, Pranoto, Y S, Moelyo, H. (2018). Kontribusi Sektor Pertanian Berdasarkan Keunggulan Wilayah di Kabupaten Bangka. Journal of Sustainable Agriculture, 33, 1: 42-49.

Vaulina, Sisca dan Elfi Rahmi. (2013). Peran Sektor Pertanian Dalam Perekonomian Kabupaten Indragiri Hilir Propinsi Riau. Jurnal Dinamika Pertanian, 28, 3:245-254.

Vaulina, Sisca dan Septina Elida. (2014). Analisis Transformasi Struktural Ekonomi di Kota Pekanbaru.Jurnal Dinamika Pertanian,29, 1: 69 - 78. 